\title{
Importance of Developing Photovoltaics-Powered Vehicles
}

\author{
Masafumi Yamaguchi ${ }^{*}$, Taizo Masuda², Takashi Nakado3, Yusuke Zushi ${ }^{4}$, Kenji Araki ${ }^{5}$, \\ Tatsuya Takamoto ${ }^{6}$, Kenichi Okumura2 ${ }^{2}$, Akinori Satou' ${ }^{2}$, Kazumi Yamada ${ }^{3}$, Yasuyuki Ota ${ }^{5}$, \\ Kensuke Nishioka ${ }^{5}$, Tsutomu Tanimoto ${ }^{4}$, Kyotaro Nakamura1, Ryo Ozaki', Nobuaki Kojima1, \\ Yoshio Ohshita1
}

\footnotetext{
${ }^{1}$ Toyota Technological Institute, Nagoya, Japan

${ }^{2}$ Toyota Motor Corporation, Susono, Japan

${ }^{3}$ Toyota Motor Corporation, Toyoota, Japan

${ }^{4}$ Nissan Motor Corporation, Yokosuka, Japan

${ }^{5}$ Miyazaki University, Miyazaki, Japan

${ }^{6}$ Sharp Corporation, Nara, Japan

Email: ^masafumi@toyota-ti.ac.jp
}

\begin{abstract}
How to cite this paper: Yamaguchi, M., Masuda, T., Nakado, T., Zushi, Y., Araki, K., Takamoto, T., Okumura, K., Satou, A. Yamada, K., Ota, Y., Nishioka, K, Tanimoto, T., Nakamura, K., Ozaki, R., Kojima, N. and Ohshita, Y. (2021) Importance of Developing Photovoltaics-Powered Vehicles. Energy and Power Engineering, 13, 147-162. https://doi.org/10.4236/epe.2021.135010
\end{abstract}

Received: April 14, 2021

Accepted: May 18, 2021

Published: May 21, 2021

Copyright $\odot 2021$ by author(s) and Scientific Research Publishing Inc. This work is licensed under the Creative Commons Attribution International License (CC BY 4.0).

http://creativecommons.org/licenses/by/4.0/

\section{(c) (i) Open Access}

\begin{abstract}
The development of photovoltaics (PV)-powered vehicles are expected to contribute to reduce $\mathrm{CO}_{2}$ emission of vehicles and create a clean energy society. This paper presents the impact of high-efficiency solar cell modules on reduction in $\mathrm{CO}_{2}$ emission, charging cost reduction for electric vehicles, and reducing storage capacity of PV-powered electric vehicles. In this paper, the effects of solar cell module efficiency upon driving distance of PV-powered vehicles are also shown. Especially, the potential of Si tandem solar cells for $\mathrm{PV}$-powered vehicle applications is discussed. This paper presents that the III-V/Si 3-junction solar cell modules with an efficiency of more than $37 \%$ have the potential of longer driving distance of $30 \mathrm{~km} /$ day average and more than $50 \mathrm{~km} /$ day on a clear day compared to an average $16 \mathrm{~km} /$ day driving by vehicles powered by $20 \%$ efficiency Si solar cell modules.
\end{abstract}

\section{Keywords}

High-Efficiency, Solar Cells, Modules, $\mathrm{CO}_{2}$ Emission Reduction, Charging Cost Reduction, PV-Powered Vehicles

\section{Introduction}

Development of the PV(photovoltaics)-powered vehicle [1] [2] [3] [4] [5] is desirable and very important in order to create a new clean energy society. Because 
the PV-powered vehicles have great potential of reducing $\mathrm{CO}_{2}$ emission from 59 $\mathrm{g}-\mathrm{CO}_{2} \mathrm{e} / \mathrm{km}$ in the case of EV (battery-powered Electric Vehicle) to $15 \mathrm{~g}-\mathrm{CO}_{2}$ e/km [4] [5]. According to the NEDO's Interim Report "PV-Powered Vehicle Strategy Committee" [2], a new broader PV market with more than $10 \mathrm{GW}$ and $50 \mathrm{GW}$ in 2030 and 2050, respectively, are expected to be established when PV-powered vehicles are developed. Cumulative PV capacity for PV-powered vehicles will be $50 \mathrm{GW}$ and $0.4 \mathrm{TW}$ in 2030 and 2050, respectively. In order to enhance recognizing the $\mathrm{PV}$-powered vehicles as major clean vehicles and to create a clean energy society based on PV, clarifying values of PV-powered vehicles and development of high-efficiency, low-cost, light-weight, 3-demensional curved, and colorful solar cell modules and other technologies are necessary.

This paper presents the importance of developing PV-powered vehicles from point views of reduction in $\mathrm{CO}_{2}$ emission and total cost reduction. Although developing high-efficiency solar cell modules has been shown to be very effective [4] [5] in order to develop attractive PV-powered vehicles, quantitative analysis for the impact of high-efficiency solar cell modules upon an increase in driving distance, reduction in $\mathrm{CO}_{2}$ emission, and total cost reduction are necessary. This paper shows the quantitative analysis for the impact of solar cell module efficiency upon extension of driving distance in Section 2 and Section 5, impact for reduction in $\mathrm{CO}_{2}$ emission in Section 3, impact for charging cost reduction and reducing storage capacity of PV-powered electric vehicles in Section 4. In addition, because the development of low-cost solar cell modules is very important for larger market growth of PV-powered vehicles, the potential of Si tandem solar cells [6] [7] [8] [9] for PV-powered vehicle application is discussed in this paper. This paper shows that III-V/Si 3-junction solar cell modules have potential of driving a distance of $30 \mathrm{~km} /$ day on average and more than $50 \mathrm{~km} /$ day on a clear day. It is demonstrated that higher efficiency solar cells have a longer driving distance.

\section{Analysis for High-Efficiency Impact on Increasing Driving Distance of PV-Powered Vehicles}

A report by the Ministry of Japan [10] [11] showed that the average trip distance of passenger car in Japan is $24 \mathrm{~km} /$ day and approximately $70 \%$ of the passenger car runs less than $30 \mathrm{~km}$ per day. Figure 1 shows changes in cumulative frequency of passenger cars in Japan as a function of daily mileage reported in reference (Hara et al. [12]) and approximation curve. Standard electric vehicles (EVs) have an electricity consumption rate of $8.8 \mathrm{~km}$ per $\mathrm{kWh}$, but after the weight reduction of passenger cars from $1400 \mathrm{~kg}$ to $600 \mathrm{~kg}$, the rate is expected to increase to $17 \mathrm{~km} / \mathrm{kWh}$ [13]. Namely, the average annual energy yield that is required for the lightweight passenger car powered by sunlight will be 642 $\mathrm{kWh} /$ year which is not an incredible value but a promising one that generated on the car exterior, when we use high-efficiency solar cell module with an efficiency of higher than $30 \%$, enables the society that majority of the Japanese passenger cars run by the solar power and without electric charging or supplying fossil fuels. Thus, we need to develop high-efficiency (over 30\%), which cannot 


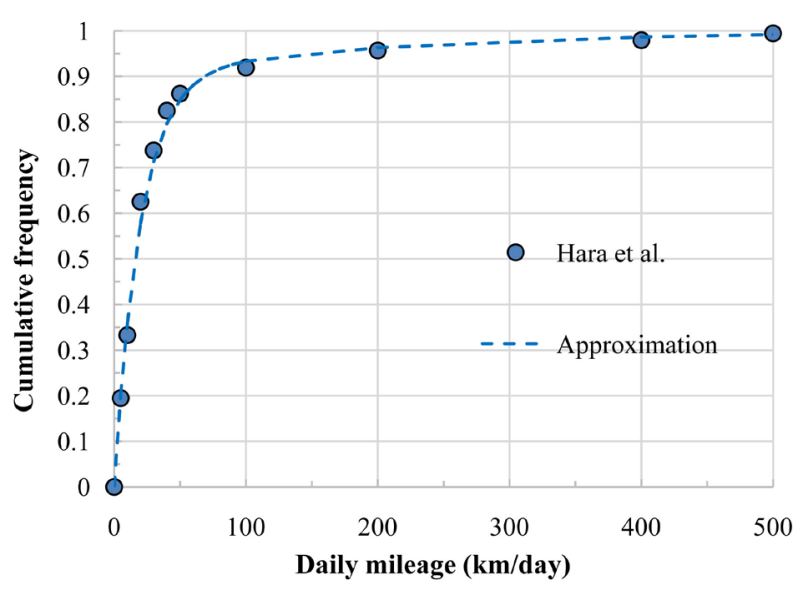

Figure 1. Changes in cumulative frequency of passenger cars in Japan as a function of daily mileage reported in references (Hara et al. [12]) and approximation curve.

be achieved by single junction Si solar cells and low-cost solar cell modules, for automotive applications.

Solar cell module efficiency impact on driving distance of PV-powered vehicles was calculated. In the calculations, the charging system efficiency of $73.9 \%$ [13] composing of cell temperature correction, maximum power point tracking, DC/DC conversion, and DC charging was assumed [5]. Figure 2 shows calculated driving distance of $\mathrm{PV}$-powered vehicles in the case of electric mileage of $9.35 \mathrm{~km} / \mathrm{kWh}$ and $10.54 \mathrm{~km} / \mathrm{kWh}[14]$ and solar irradiance $4 \mathrm{kWh} / \mathrm{m}^{2} /$ day as a function of $\mathrm{PV}$ module nominal power in comparison with practical data for Toyota Prius 2019 [5], Toyota Prius 2017 [5] [14], and Sono Motor Sion [15]. The Toyota Prius 2019 (demonstration car) [5] installed with about 30.9\% efficiency module and output power of $860 \mathrm{~W}$ has shown $36.6 \mathrm{~km} /$ day and 29.9 $\mathrm{km} /$ day driving distance at solar irradiance of $6.2 \mathrm{kWh} / \mathrm{m}^{2} /$ day and $4.1 \mathrm{kWh} /$ $\mathrm{m}^{2} /$ day, respectively. If sunny day (solar irradiance of $8.4 \mathrm{~kW} / \mathrm{m}^{2} /$ day), the Toyota demonstration car can run $49.5 \mathrm{~km} /$ day. On the other hands, the Sono Motor Sion [15] installed 20\% - 22\% efficiency module has shown $34 \mathrm{~km} /$ day driving distance in clear day (solar irradiance of $8.4 \mathrm{~kW} / \mathrm{m}^{2} /$ day) and $15.3 \mathrm{~km} /$ day average (solar irradiance of $3.84 \mathrm{~kW} / \mathrm{m}^{2} /$ day). It is clear that the vehicles installed with the higher-efficiency solar cell modules are promising for realizing the longer distance driving as shown in Figure 2. Although detail analysis of driving distance is shown in Section 5, our analytical procedure shows good measure of solar cell module efficiency dependence upon driving distance of PVpowered vehicles.

\section{Analysis for High-Efficiency Impact on Reduction in $\mathrm{CO}_{2}$ Emission by PV-Powered Vehicles}

Effects of introduction of high-efficiency solar cell modules into electric vehicles (EVs) upon reduction in $\mathrm{CO}_{2}$ emission were analysed. Average $\mathrm{CO}_{2}$ emission intensity $\mathrm{CI}_{\mathrm{EV}}$ for EVs is reported to be $462 \mathrm{~g}-\mathrm{CO}_{2} \mathrm{e} / \mathrm{kWh}$ [16]. EV usage $\mathrm{CO}_{2}$ emission $\mathrm{CE}_{\mathrm{EV}}$ is expressed by: 


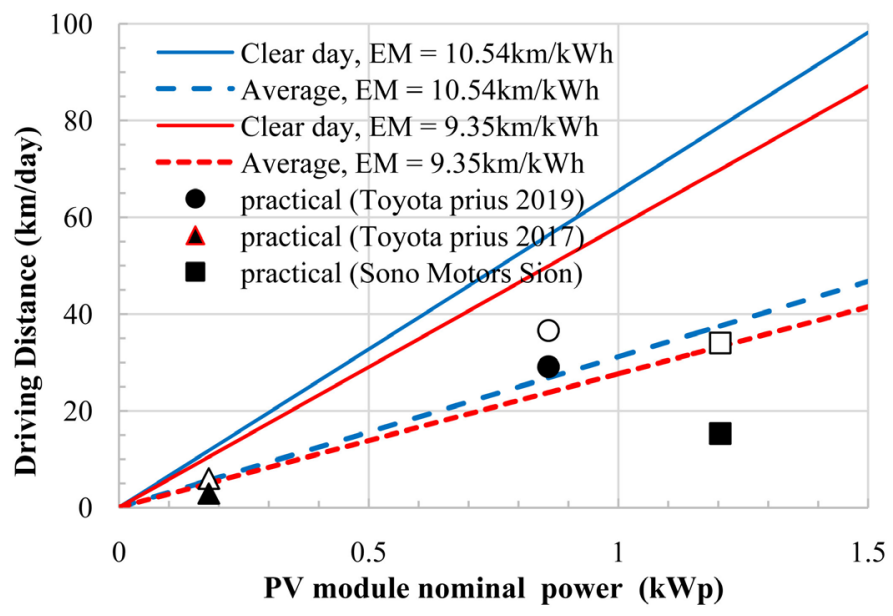

Figure 2. Calculated driving distance of PV-powered vehicles in the case of electric mileage of $9.35 \mathrm{~km} / \mathrm{kWh}$ and $10.54 \mathrm{~km} / \mathrm{kWh}$, and solar irradiance $4 \mathrm{kWh} / \mathrm{m}^{2} /$ day as a function of PV module nominal power in comparison with practical data for Toyota Prius 2019 [5], Toyota Prius 2017 [5] [14] and Sono Motor Sion [15]. White colour plots show clear day data and black colour plots shows average driving distance.

$$
\begin{aligned}
\mathrm{CE}_{\mathrm{EV}}\left[\mathrm{g}-\mathrm{CO}_{2} \mathrm{e} / \mathrm{km}\right] & =\mathrm{CI}_{\mathrm{EV}}\left[\mathrm{g}-\mathrm{CO}_{2} \mathrm{e} / \mathrm{Wh}\right] \mathrm{EC}_{\mathrm{EV}}[\mathrm{Wh} / \mathrm{km}] \\
& =\mathrm{CI}_{\mathrm{EV}}\left[\mathrm{g}-\mathrm{CO}_{2} \mathrm{e} / \mathrm{Wh}\right] / \mathrm{EM}[\mathrm{km} / \mathrm{Wh}]
\end{aligned}
$$

where $\mathrm{EC}_{\mathrm{EV}}$ is the $\mathrm{EV}$ energy consumption and $\mathrm{EM}$ is the electric mileage.

On the other hands, $\mathrm{CO}_{2}$ emission $\mathrm{CE}_{\mathrm{PV} \text {-production }}$ for $\mathrm{PV}$-production is thought to be given by:

$$
\begin{aligned}
& \mathrm{CE}_{\mathrm{PV} \text {-production }}\left[\mathrm{g}-\mathrm{CO}_{2} \mathrm{e} / \mathrm{km}\right] \\
& =\mathrm{P}_{\mathrm{pv}}[\mathrm{W}] \mathrm{CI}_{\mathrm{PV}}\left[\mathrm{g}-\mathrm{CO}_{2} \mathrm{e} / \mathrm{W}\right] /\left(\mathrm{DD}[\mathrm{km} / \text { day }] \tau_{\mathrm{PV}}[\text { years }]\right)
\end{aligned}
$$

where $\mathrm{P}_{\mathrm{pv}}$ is the module output power, $\mathrm{CI}_{\mathrm{PV}}$ is the carbon intensity per unit $\mathrm{W}$, $\mathrm{DD}$ is the driving distance, and $\tau_{\mathrm{PV}}$ is the lifetime for PV modules. In this study, 1008 g- $\mathrm{CO}_{2} \mathrm{e} / \mathrm{W}$ was assumed as $\mathrm{CI}_{\mathrm{PV}}$ according to the reference [17] and 15 years were assumed as $\tau_{\mathrm{PV}}$ because of $\mathrm{PV}$-powered vehicle applications. The $\mathrm{PV}$-EV usage $\mathrm{CO}_{2}$ emission $\mathrm{CE}_{\mathrm{PV}-\mathrm{V}}$ is expressed by:

$$
\mathrm{CE}_{\mathrm{PV}-\mathrm{EV}}\left[\mathrm{g}-\mathrm{CO}_{2} \mathrm{e} / \mathrm{km}\right]=\mathrm{CE}_{\mathrm{EV}}\left[\mathrm{g}-\mathrm{CO}_{2} \mathrm{e} / \mathrm{km}\right]+\mathrm{CE}_{\mathrm{PV} \text {-production }}\left[\mathrm{g}-\mathrm{CO}_{2} \mathrm{e} / \mathrm{km}\right]
$$

As shown in Figure 1, tendency for cumulative frequency CF of passenger cars in Japan as a function of daily mileage was approximated by the following equation:

$$
\mathrm{CF}=0.9 *\{1-\operatorname{EXP}(-\mathrm{DD}[\mathrm{km} / \mathrm{day}] / 20)\} / 0.1 *\{1-\operatorname{EXP}(-\mathrm{DD}[\mathrm{km} / \text { day }] / 200)\}
$$

As shown in Section 2, driving distance DD was estimated by using the following equation:

$$
\mathrm{DD}[\mathrm{km} / \text { day }]=\mathrm{SI}\left[\mathrm{kWh} / \mathrm{m}^{2} / \mathrm{day}\right] \operatorname{PR} \eta[\%] 0.01 \mathrm{~A}\left[\mathrm{~m}^{2}\right] \mathrm{EM}[\mathrm{km} / \mathrm{kWh}]
$$

where SI is the solar irradiance, PR is the performance ratio of PV system and 0.739 [13] was used as the PR in this case, $\eta$ is the solar cell module efficiency, A 
is the area of solar cell module and $3 \mathrm{~m}^{2}$ was used as A this time, and EM is the electric mileage. In the calculation, sharing ratio of EV mode and PV mode for PV-EV was estimated by driving distance DD and Equations (1)-(5).

Figure 3 shows calculated results for $\mathrm{CO}_{2}$ emission of $\mathrm{PV}$-powered electric vehicles (PV-EV) installed with solar cell modules with different efficiencies as a function of electric mileage in comparison with those of electric vehicles (EV) and PV production. As shown in Figure 3, the EV and PV-EV with larger electric mileage have large benefits for reduction in $\mathrm{CO}_{2}$ emission. It is clear in Figure 3 that the PV-EV installed with the higher efficiency solar cell modules has great potential of reduction in $\mathrm{CO}_{2}$ emission.

Figure 4 shows calculated results for reduction ratio of $\mathrm{CO}_{2}$ emission of $\mathrm{PV}$-powered electric vehicles (PV-EV) installed with solar cell modules with different efficiencies compared to $\mathrm{CO}_{2}$ emission of the EV and $\mathrm{PV}$ production as a function of electric mileage. As shown in Figure 4, reduction of $55 \%-73 \% \mathrm{CO}_{2}$ emission will be realized by using the PV-powered vehicles with electric mileage of $10 \mathrm{~km} / \mathrm{kWh}$ and the higher-efficiency solar cell modules have possibility of great contribution to $\mathrm{CO}_{2}$ emission reduction in the $\mathrm{PV}$-powered vehicles.

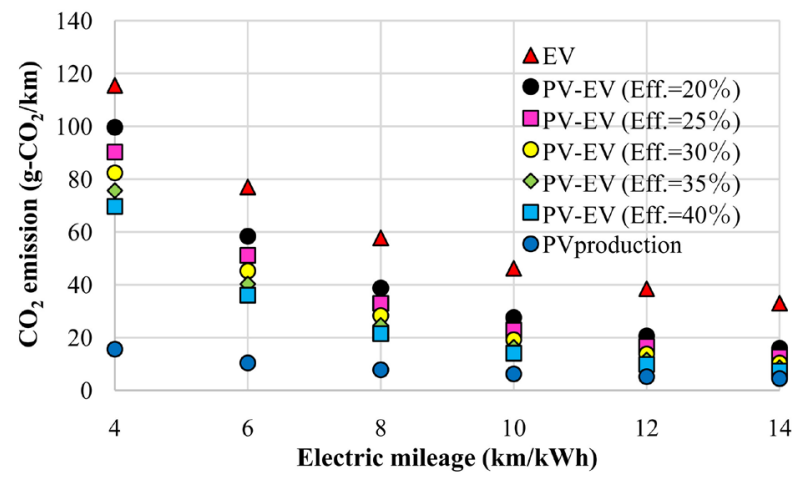

Figure 3. Calculated results for $\mathrm{CO}_{2}$ emission of $\mathrm{PV}$-powered electric vehicles (PV-EV) in stalled with solar cell modules with different efficiencies as a function of electric mileage in comparison with those of electric vehicles (EV) and PV production.

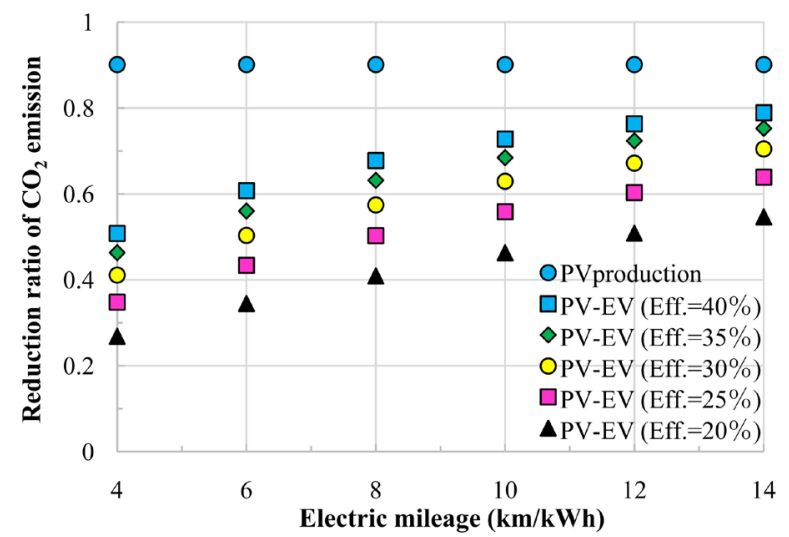

Figure 4. Calculated results for reduction ratio of $\mathrm{CO}_{2}$ emission of $\mathrm{PV}$-powered electric vehi cles (PV-EV) installed with solar cell modules with different efficiencies compared to $\mathrm{CO}_{2}$ emission of the EV and PV production as a function of electric mileage. 


\section{Analysis for High-Efficiency Impact on Total Cost Reduction of Electric Vehicles by PV-Powered Vehicles}

\subsection{Saving of EV Charging Cost}

Electricity cost saving for EV charging by usage of PV was analysed in this study. $\mathrm{EV}$ energy consumption $\mathrm{EC}$ is given by:

$$
\mathrm{EC}[\mathrm{kWh} / \text { year }]=\mathrm{DD}[\mathrm{km} / \text { year }] / \mathrm{EM}[\mathrm{km} / \text { year }]
$$

Charging electricity cost $\mathrm{CC}$ of EV charging is given by:

$$
\mathrm{CC}[\$ / \text { year }]=\mathrm{EC}[\mathrm{kWh} / \text { year }] \mathrm{EP}[\$ / \mathrm{kWh}]
$$

where EP is the household electricity and is $\$ 0.207 / \mathrm{kWh}[18]$ in Japan in 2020.

PV-EV cost saving $\triangle \mathrm{CS}_{\mathrm{PV}-\mathrm{EV}}$ was calculated by using the following equation:

$$
\Delta \mathrm{CS}_{\mathrm{PV}-\mathrm{EV}}[\$ / \text { year }]=-\Delta \mathrm{E}_{\text {grid }}[\mathrm{kWh} / \text { year }] \mathrm{EP}[\$ / \mathrm{kWh}]
$$

In the similar way with analytical procedure described in Section 3, effectiveness of high-efficiency solar cell modules for cost saving of EV charging was analysed. By using Equation (4) for tendency for cumulative frequency CF of passenger cars in Japan as a function of daily mileage shown in Figure 1, charging possibility of PV-powered vehicles was calculated. Cost saving for charging of EV was calculated by considering reduction in charging frequency due to usage of PV and using Equation (8).

Figure 5 shows calculated results for charging electricity cost of EV and PV$\mathrm{EV}$ as a function of electric millage by assuming $30 \mathrm{~km} /$ day as average daily driving distance. The results show effectiveness of high-efficiency solar cell modules for charging electricity cost saving of electric vehicles. For example, electricity cost saving is $\$ 254.1$ year for $40 \%$ module and $\$ 149.1 /$ year for $20 \%$ module in the case of electric mileage of $4 \mathrm{~km} / \mathrm{kWh}$, $\$ 167.2 /$ year for $40 \%$ module and $\$ 117.8 /$ year for $20 \%$ module in the case of electric mileage of $10 \mathrm{~km} / \mathrm{kWh}$ as shown in Figure 5.

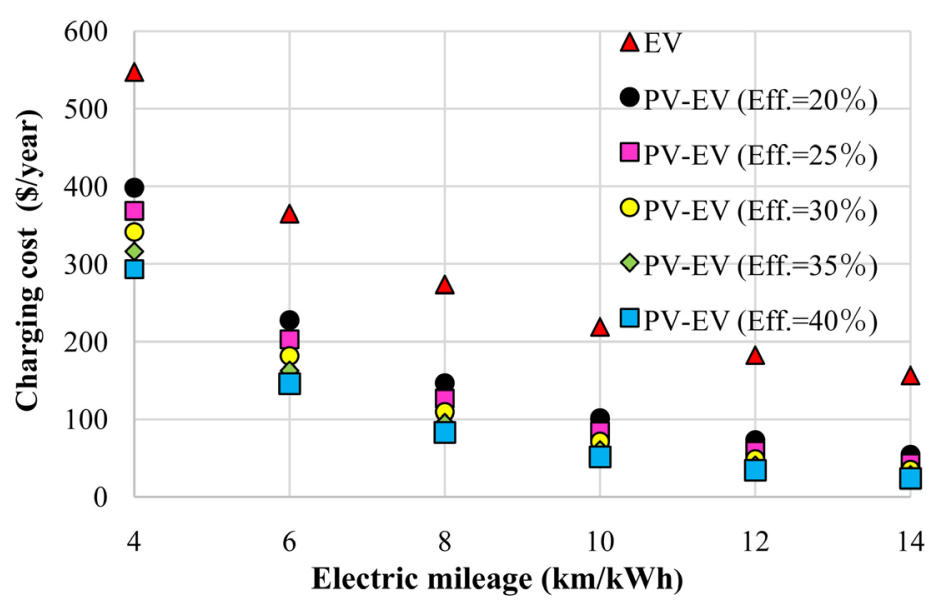

Figure 5. Calculated results for charging electricity cost of EV and PV-EV as a function of elec tric millage by assuming $30 \mathrm{~km} /$ day as average daily driving distance. 


\subsection{Saving of EV Battery Capacity}

In general, the electric vehicles (EV) have high battery capacity from about 40 to $95 \mathrm{kWh}$ [19] as shown in Figure 6. Figure 6 shows calculated results for changes in driving rage of EV [19] as a function of battery capacity and electric mileage (EM). Driving range of the EV is well known to be dependent on battery capacity and EM. Therefore, total cost reduction of the EV is thought to be possible because cost reduction of solar cell modules has been progressed recent years.

Here, estimated driving distance $\mathrm{DD}_{\text {est. }}$ was calculated by the following equation:

$$
\mathrm{DD}_{\text {est. }}[\mathrm{km}]=\mathrm{BC}[\mathrm{kWh}] \mathrm{EM}[\mathrm{km} / \mathrm{kWh}]
$$

where BC is the battery capacity. Figure 7 shows correlation between estimated driving distance and practical driving distance of various vehicles [19]. Practical driving distance $\mathrm{DD}_{\text {prac. }}$ is correlates with $\mathrm{DD}_{\text {est. }}$

$$
\mathrm{DD}_{\text {prac. }}=\mathrm{DD}_{\text {est. }} / 0.9
$$

Figure 8 shows Price trend in Li-ion battery pack and price prediction [20]. According to the Bloomberg New Energy Finance [20], the price of EV battery pack was $\$ 1183 / \mathrm{kWh}$ in 2010 and average price was $\$ 156 / \mathrm{kWh}$ in 2019 . By 2024

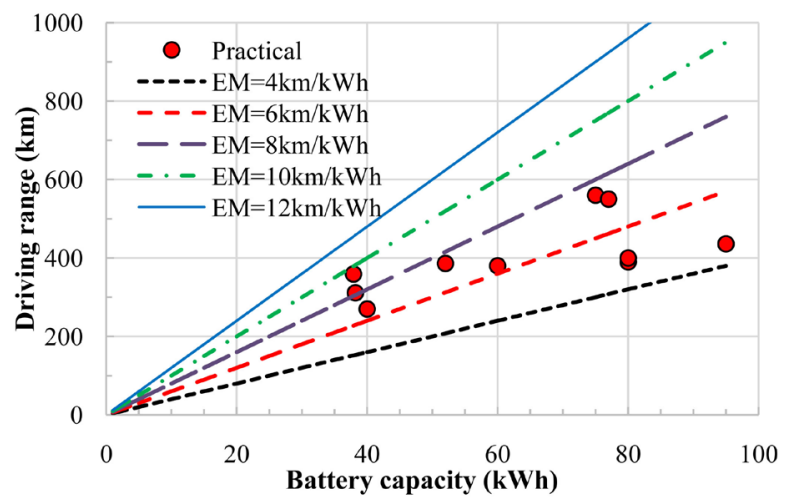

Figure 6. Calculated results for changes in driving rage of EV [19] as a function of battery ca pacity and electric mileage (EM).

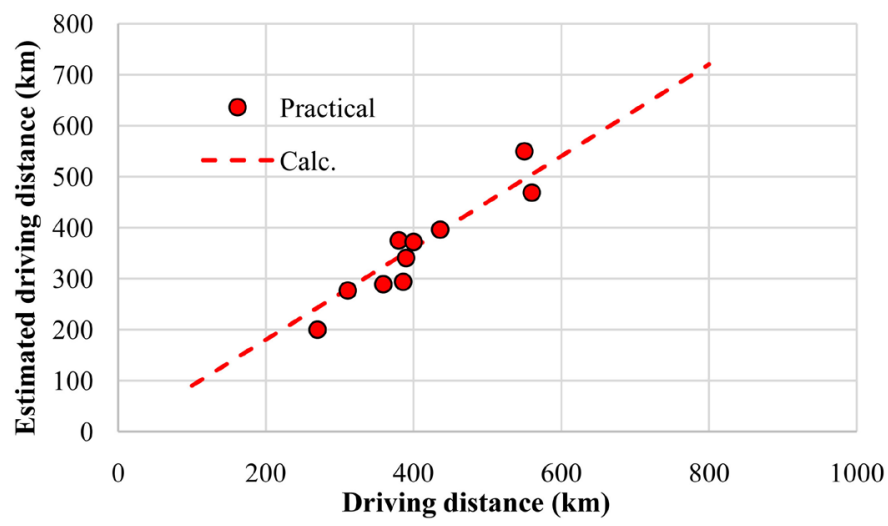

Figure 7. Correlation between estimated driving distance and practical driving distance of various vehicles [19]. 


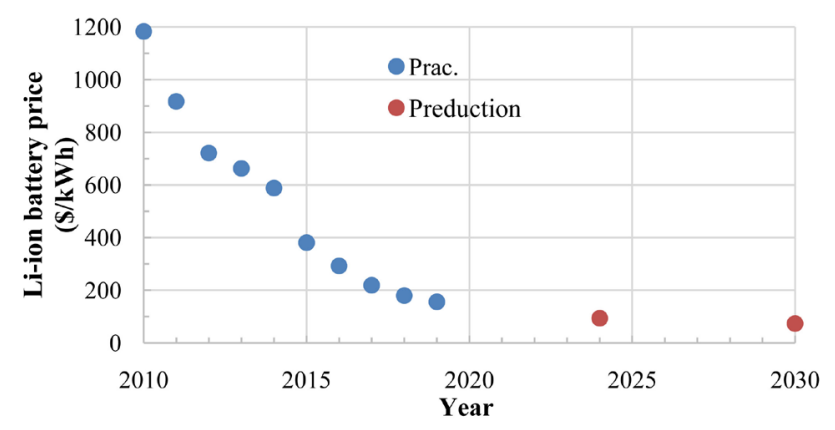

Figure 8. Price trend in Li-ion battery pack and price prediction [20].

and 2030 , the price was predicted to be $\$ 94 / \mathrm{kWh}$ and $\$ 74 / \mathrm{kWh}[20]$ as shown in Figure 8. Here, price reduction potential of the PV-EV compared to the EV was analysed because the PV-EV has potential of reducing battery capacity of PV$\mathrm{EV}$. In the similar way with reduction in $\mathrm{CO}_{2}$ emission by the PV-EV compared to the EV, possibility of reducing battery capacity was calculated by using tendency for cumulative frequency CF of passenger cars in Japan as a function of daily mileage approximated by Equation (4).

Figure 9 shows changes in cumulative frequency estimated from Equations (4), (9) and (10) for battery capacity of passenger cars as a function of electric mileage. If $99.0 \%$ of passenger car satisfy battery capacity of PV-EV, saving battery capacity of $37.5 \mathrm{KWh}$ and $24.5 \mathrm{kWh}$ in the cases of electric mileage of 12 $\mathrm{km} / \mathrm{kWh}$ and $8 \mathrm{~km} / \mathrm{kWh}$ compared to average battery capacity (63.5 kWh) is thought to be possible. However, it depends on choice of motor companies and passenger car customers.

Here, effects of saving batter capacity by usage of solar cell modules were analyzed. In the calculation, possibility of price reduction of battery part of the $\mathrm{PV}-\mathrm{EV}$ due to reducing battery capacity as a result of support by $\mathrm{PV}$ as a function of solar cell module efficiency $\eta$ in the cases of battery price of $\$ 150 / \mathrm{kWh}$, $\$ 100 / \mathrm{kWh}$ and $\$ 50 / \mathrm{kWh}$ by using (9) and (10). Figure 10 shows calculated results for price reduction potential of $\mathrm{PV}-\mathrm{EV}$ as a function of solar cell module efficiency in the cases of battery price (BP) of $\$ 150 / \mathrm{kWh}, \$ 100 / \mathrm{kWh}$ and $\$ 50 /$ $\mathrm{kWh}$. It is clear in Figure 10 that the vehicles installed with the higher efficiency solar cell modules have potential of the larger battery cost saving. However, saving of battery capacity depends on choice of motor companies and passenger car customers.

\subsection{Analysis for Cost Target of Solar Cell Modules for PV-Powered Vehicles}

In this section, target cost TC of solar cell modules can be estimated by considering compensation of electricity cost saving by usage of solar cell modules by using the following equation. This time, only effects of charging electricity price saved on cost reduction of vehicles were considered because effects of battery capacity saving of the PV-EV are dependent on choice of motor companies and passenger car customers. 


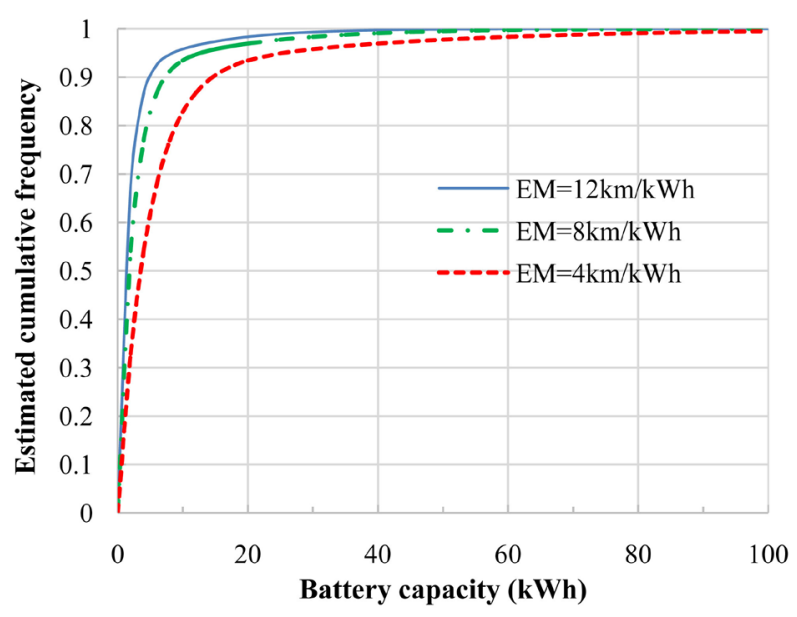

Figure 9. Changes in cumulative frequency estimated from Equations (4), (9) and (10) for battery capacity of passenger cars as a function of electric mileage.

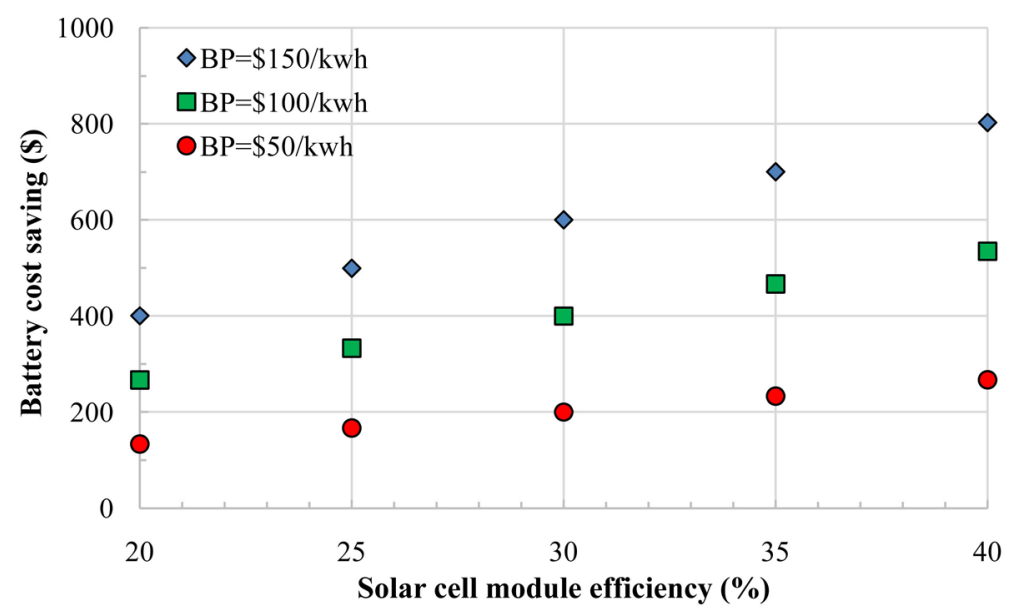

Figure 10. Calculated results for price reduction potential of PV-EV as a function of solar cell module efficiency in the cases of battery price (BP) of $\$ 150 / \mathrm{kWh}, \$ 100 / \mathrm{kWh}$ and $\$ 50 / \mathrm{kWh}$.

$$
\mathrm{TC}[\$ / \mathrm{Wp}]=\Delta \mathrm{CS}_{\mathrm{PV}-\mathrm{EV}}[\$ / \text { year }] * \tau_{\mathrm{EV}}[\text { year }] / \mathrm{P}_{\mathrm{PV}}[\mathrm{Wp}]
$$

where $\tau_{\mathrm{EV}}$ is the vehicle lifetime. Figure 11 shows estimated target cost of solar cell modules as a function of electric mileage and lifetime of vehicles. As the cost target of solar cell modules for the PV-EV, $\$ 2.5-3.3 / \mathrm{Wp}$ is estimated in the case of electric mileage of $10 \mathrm{~km} / \mathrm{kWh}$.

According to the survey reports [12] [21], passenger car customers prefer low-cost solar cell modules for PV-powered vehicles. Cost reduction of highefficiency solar cell modules is also significant for PV-powered vehicle applications. Figure 12 shows our calculated results [22] for changes in cost of PV module and system as a function of production volume of PV modules and PV system cost target in comparison with those of cost analytical results by NREL [7] [23] and PV price data for Toyota Prius. The PV price estimated [4] [5] are about $\$ 30 / \mathrm{W}$ for Toyota Prius shipped in 2009 and $\$ 12 / \mathrm{W}$ for New Prius 


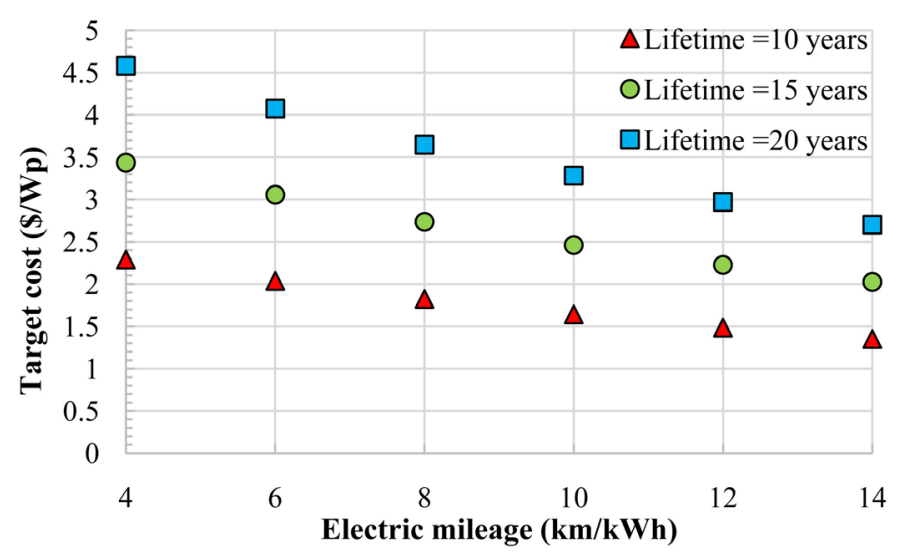

Figure 11. Estimated target cost of solar cell modules as a function of electric mileage and life time of vehicles.

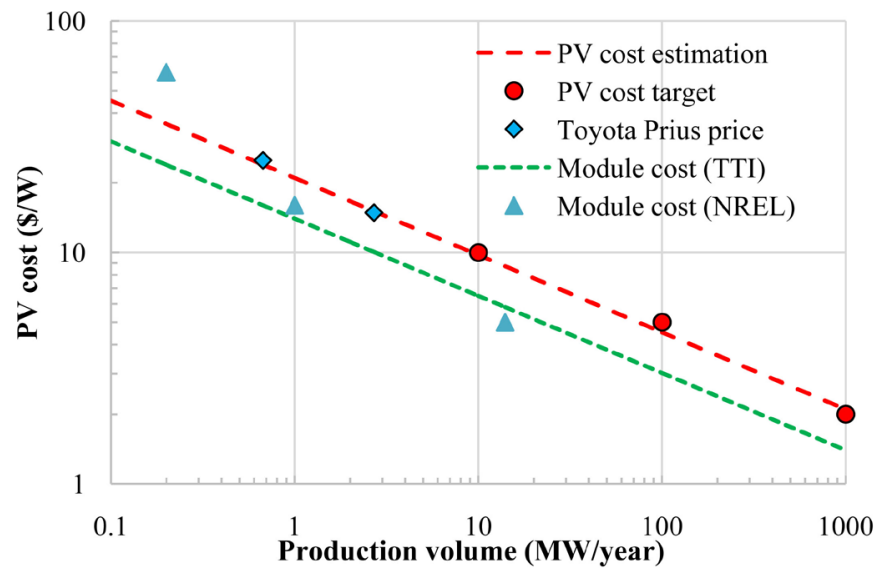

Figure 12. Calculated results for changes in cost of PV module and system as a function of production volume of PV modules and PV system cost target in comparison with those of cost analytical results by NREL and costs estimated from PV price data for Toyota Prius HEV.

shipped in 2017, respectively. Cost of PV modules $\mathrm{C}_{\text {module }}$ was estimated as a function of production volume $\mathrm{V}_{\mathrm{PV}}$ by assuming the following equation [22]:

$$
\mathrm{C}_{\text {module }}[\$ / \mathrm{W}]=14 \times\left(1 / \mathrm{V}_{\mathrm{PV}}[\mathrm{MW} / \text { year }]\right)^{1 / 3}
$$

$\mathrm{PV}$ cost $\mathrm{C}_{\mathrm{PV}}$ was estimated as a function of production volume $\mathrm{V}_{\mathrm{PV}}$ by considering PV price and production volume estimated from information [24] for Toyota Prius and assuming the following equation:

$$
\mathrm{C}_{\mathrm{PV}}[\$ / \mathrm{W}]=1.5 \times 14 \times\left(1 / \mathrm{V}_{\mathrm{PV}}[\mathrm{MW} / \text { year }]\right)^{1 / 3}
$$

The results suggest that there are many possible ways to achieve low-cost III-V based solar cell module, such as scaling up production volume to $100 \mathrm{MW} /$ year with a high-speed growth method and Si tandem solar cells by combining III-V or perovskite or II-VI or chalcopyrite or kesterite and Si bottom cell in addition to static low concentrator PV. As shown in Figure 12, cost targets of $\$ 30 / \mathrm{W}$ for production volume of $1 \mathrm{MW} /$ year, $\$ 5 / \mathrm{W}$ for $100 \mathrm{MW} /$ year and $\$ 2 / \mathrm{W}$ 
for $1000 \mathrm{MW} /$ year are thought to be reasonable by considering PV price for Toyota Prius. Estimated target cost $(\$ 2.5-3.3 / \mathrm{Wp})$ of solar cell modules shown in Figure 11 will be realized. We will describe each way in the next section.

\section{Analysis for Potential of PV-Powered Vehicles by Using Si Tandem Solar Cells}

As described above, the higher-efficiency solar cell modules have great potential for the longer driving distance, reduction in $\mathrm{CO}_{2}$ emission and saving charging cost for electric vehicles. However, cost reduction of solar cell modules is also very important for attractive PV-powered vehicles. The Si-based tandem cells that combine Si with other materials such as III-V compound, II-VI compound, perovskite chalcopyrite, and so forth are desirable for realizing super highefficiency and low cost, as shown in Figure 12. The Si tandem solar cells [6] [7] [8] [9] have been receiving considerable attention because of its potentials.

Previously, we have analyzed the efficiency potential of various solar cells by using our analytical procedure [25] [26] [27]. In the analysis for efficiency potential of Si tandem solar cells, the similar method and parameters reported in our previous papers [25] [26] [27] were used. Figure 13 shows calculated 1-sun efficiency of III-V/Si triple-junction including our results and III-V/Si dualjunction tandem solar cells and perovskite/Si dual-junction tandem solar cells as a function of average external radiative efficiency (ERE) and resitance loss $r_{s}$ $+1 / r_{\text {ss. }}$. White rectangular and circle plots show InGaP/GaAs/InGaAs triplejunction and InGaP/GaAs dual-junction tandem solar cells. Previously, we achieved $28.2 \%$ efficiency $\left(0.95 \mathrm{~cm}^{2} \mathrm{da}\right)$ [6] [28] [29] in 2016, and Sharp demonstrated 33\% [30] (3.604 $\mathrm{cm}^{2}$ ap) in 2017, with mechanically stacked In$\mathrm{GaP} / \mathrm{GaAs} / \mathrm{Si}$ 3-junction solar cells. At present, the III-V/Si 3-junction and 2-junction tandem solar cells have shown higher efficiency with 35.9\% [7] (1.002 $\left.\mathrm{cm}^{2} \mathrm{da}\right)$ and $32.8 \%$ [7] $\left(1.003 \mathrm{~cm}^{2} \mathrm{da}\right)$ compared to perovskite/Si 2-junction

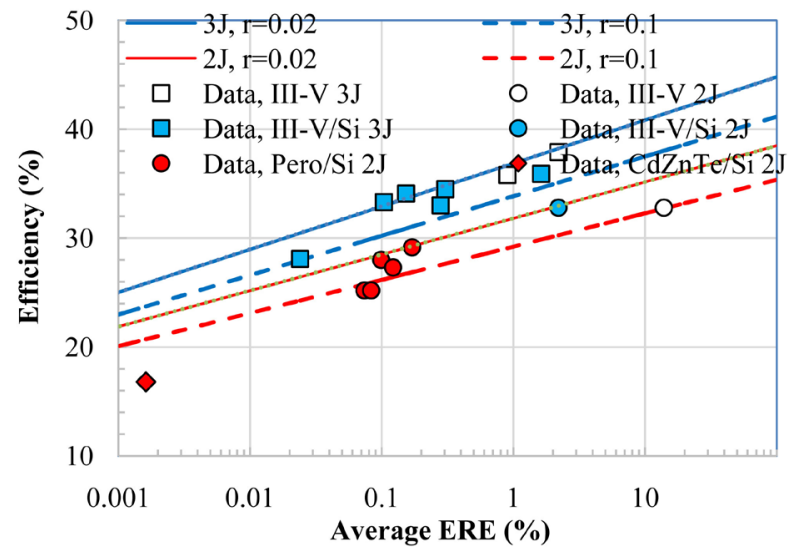

Figure 13. Calculated 1-sun efficiency of III-V/Si triple-junction including our results III-V/Si and dual-junction tandem solar cells and perovskite/Si dual-junction tandem solar cells as a function of average external radiative efficiency (ERE) and resistance loss ${ }_{s}+$ $1 / \mathrm{r}_{\mathrm{ss}}$. White rectangular shows InGaP/GaAs/InGaAs triple-junction tandem solar cells. 
tandem solar cells with efficiencies of 29.15\% (1.030 $\left.\mathrm{cm}^{2} \mathrm{da}\right)$ [9] and CdZnTe/Si 2 -junction tandem solar cell with an efficiency of $16.8 \%\left(0.126 \mathrm{~cm}^{2}\right.$ mesa area) [31]. Such an efficiency difference is thought to be a difference in material quality. For example, the external radiative efficiency values (ERE) are $1 \%-2.2 \%$ for III-V/Si tandem cells, $0.1 \%-0.17 \%$ for perovskite/Si tandem cells, $0.0016 \%$ for $\mathrm{CdZnTe} / \mathrm{Si}$ tandem cells. Therefore, a material quality is critical for further improvements in the performance of Si tandem solar cells. Although efficiency (35.9\%) [7] of 4-terminal mechanical stacked InGaP/GaAs/Si 3-junction tandem solar cells is close to that of InGaP/GaAs/InGaAs 3-junction cells (37.9\% for $1.047 \mathrm{~cm}^{2}$ ap) [32], resistance loss is higher as shown in Figure 13. Resistance loss for the perovskite/Si tandem cells and $\mathrm{CdZnTe} / \mathrm{Si}$ tandem cells are much higher compared to the III-V/Si tandem solar cells as s shown in Figure 13. The 3 -junction and 2-junction Si tandem solar cells have an efficiency potential of $42 \%$ and $36 \%$, respectively.

Figure 14 shows calculated results for driving distance of vehicles powered by perovskite/Si 2-junction, III-V/Si 2-junction and III-V/Si 3-juncttion tandem solar cells and III-V 3-junction tandem solar cells and module as a function of module efficiency and temperature coefficient (TC) in comparison with estimated values of vehicles powered by perovskite/Si 2 -junction, III-V/Si 2-junction and III-V/Si 3-juncttion tandem solar cells and III-V 3-junction tandem solar cells and module and actual driving distance calibrated of the Prius 2019 [5] powered by 3-junction solar cell module and the Sono Motors Sion [15] powered by back-contact $\mathrm{Si}$ solar cell module. In the calculation, driving distance

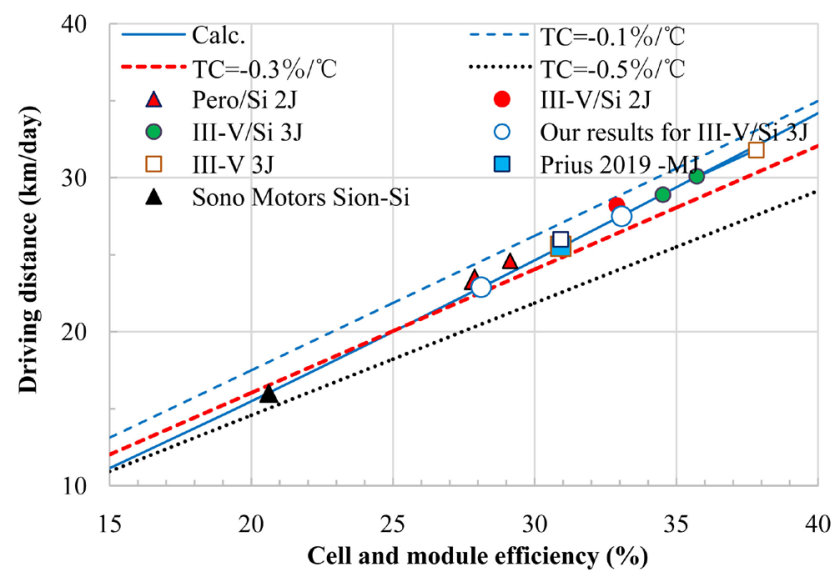

Figure 14. Calculated results for driving distance of vehicles powered by perovskite/Si 2 -junction, II-V/Si 2 -junction and III-V/Si 3-juncttion tandem solar cells and III-V 3 -junction tandem solar cells and module as a function of module efficiency and temperature coefficient (TC) in comparison with estimated values of vehicles powered by perovskite/Si 2-junction, II-V/Si 2-junction and III-V/Si 3-juncttion tandem solar cells and III-V 3-junction tandem solar cells and module and actual driving distance calibrated of the Toyota Prius 2019 [5] powered by 3-junction solar cell module and the Sono Motors Sion [15] powered by back-contact Si solar cell module. The blue rectangular shows actual driving distance of the Toyota Prius 2019 and the black triangle shows actual driving distance of Sono Mortors Sion. 
by PV-powered vehicles with electric mileage of $9.35 \mathrm{~km} / \mathrm{kWh}$ (in the case of Toyota demonstration car [5]) and $3 \mathrm{~m}^{2}$ area modules under average solar irradiance of $4 \mathrm{kWh} / \mathrm{m}^{2} /$ day was estimated. The III-V/Si 3-junction tandem solar cell modules with an efficiency of $37.9 \%$ and $30.9 \%$ have potential driving distance of $31.8 \mathrm{~km} /$ day and $25.6 \mathrm{~km} /$ day (that is quite agreement with actual driving distance of $26 \mathrm{~km} /$ day by Toyota demonstration car [5]) under solar irradiance of $4 \mathrm{kWh} / \mathrm{m}^{2} /$ day. If $29.15 \%$ efficiency perovskite/Si 2 -junction tandem solar cell modules, those have potential driving distance of $24.6 \mathrm{~km} /$ day under solar irradiance of $4 \mathrm{kWh} / \mathrm{m}^{2} /$ day. On the other hand, the Si solar cell modules with an efficiency of $20.6 \%$ have potential driving distance of $16 \mathrm{~km} /$ day (that is quite agreement with actual driving distance of $16 \mathrm{~km}$ /day by Sono Motor Sion [15]) under solar irradiance of $4 \mathrm{kWh} / \mathrm{m}^{2} /$ day. The III-V/Si 3-junction solar cell modules have potential of driving distance of $30 \mathrm{~km}$ /day average and more than $50 \mathrm{~km}$ /day on a clear day. It is demonstrated in Figure 14 that the higher efficiency solar cell modules can provide the longer distance driving. Our analytical procedure shows good measure of solar cell module efficiency dependence upon driving distance of PV-powered vehicles.

\section{Summary}

The development of PV-powered vehicle applications is desirable and very important for reducing $\mathrm{CO}_{2}$ emission of vehicles and the creation of a mobility society. This paper presented quantitative analysis for the impact of solar cell module efficiency upon extension of driving distance, reduction in $\mathrm{CO}_{2}$ emission, charging cost reduction, and reducing the storage capacity of PV-powered electric vehicles.

This paper has shown that reduction of $55 \%-73 \% \mathrm{CO}_{2}$ emission will be realized by using the PV-powered vehicles with electric mileage of $10 \mathrm{~km} / \mathrm{kWh}$ and the higher-efficiency solar cell modules have the possibility of great contribution to $\mathrm{CO}_{2}$ emission reduction in the PV-powered vehicles.

The results also have shown the effectiveness of high-efficiency solar cell modules for charging electricity cost saving of electric vehicles. For example, electricity cost saving is $\$ 254.1$ year for $40 \%$ module and $\$ 149.1 /$ year for $20 \%$ module in the case of electric mileage of $4 \mathrm{~km} / \mathrm{kWh}, \$ 167.2 /$ year for $40 \%$ module, and $\$ 117.8 /$ year for $20 \%$ module in the case of electric mileage of $10 \mathrm{~km} /$ kWh.

In this paper, analytical results for the effectiveness of high-efficiency solar cell modules from point-views of driving distance, reduction in $\mathrm{CO}_{2}$ emission, and saving EV charging cost were shown. The Si tandem solar cells are expected to have significant potential for PV-powered vehicle applications because of high efficiency with efficiencies of more than $42 \%$ under 1-sun AM1.5 G, lightweight and low-cost potential. It is summarized that the III-V/Si 3-junction solar cell modules have the potential of driving distance of $30 \mathrm{~km} /$ day on average and more than $50 \mathrm{~km} /$ day on a clear day compared to average $16 \mathrm{~km} /$ day driving by vehicles powered by $20 \%$ efficiency Si solar cell modules. 
Although this paper has shown that high-efficiency solar cell modules have great potential for longer driving distance, reduction in $\mathrm{CO}_{2}$ emission, and charging cost saving of electric vehicles, further cost reduction is necessary. Challenging development of super high-efficiency solar cell modules, development of unique solar cell modules with color variation and 3-dimensional surface in addition to solving some problems of partial shading mechanical stress and temperature rise is very important for major contribution by PV-powered vehicles in the transport sector.

\section{Acknowledgements}

The authors wish to express sincere thanks to the NEDO and METI for their support, and to Dr. H. Yamada, Mr. M. Yamazaki, Mr. M. Ishimura, Mr. T. Sato, Mr. K. Fukushima and Mr. M. Iwata, NEDO, Dr. K-H. Lee, Toyota Tech. Inst., Prof. N. Yamada and Dr. D. Sato, Nagaoka Univ. Tech., Prof. T. Hirota, Waseda Univ., Dr. K. Komoto, Mizuho, Inf. Res. Inst., Dr. M. Tanaka, PVTEC, and members of the NEDO's PV-powered Vehicle Strategy Committee for their helpful discussion and providing fruitful information.

\section{Conflicts of Interest}

The authors declare no conflicts of interest regarding the publication of this paper.

\section{References}

[1] Yamaguchi, M., Araki, K., Lee, K.H., Kojima, N., Masuda, T., Kimura, K., Satou, A. and Yamada, H. (2017) Towards Creation of Mobility Society Using Solar Energy. Proceedings of the 5 th IEEE International Conference on Smart Energy Grid Engineering, Oshawa, 14-17 August 2017, 394. https://doi.org/10.1109/SEGE.2017.8052832

[2] NEDO (2018) Interim Report "PV-Powered Vehicle Strategy Committee". http://www.nedo.go.jp/english/index.html

[3] Rodriguez, A.S., Santana, T., MacGill, I., Ekins-Daukes, N.J. and Reinders, A. (2019) A Feasibility Study of Solar PV-Powered Electric Cars Using Aninterdisciplinary Modeling Approach for the Electricity Balance, $\mathrm{CO}_{2}$ Emissions, and Economic Aspects: The Cases of the Netherlands, Norway, Brazil, and Australia. Progress in Photovoltaics, 28, 517. https://doi.org/10.1002/pip.3202

[4] Yamaguchi, M., Masuda, T., Araki, K., Sato, D., Lee, K.-H., Kojima, N., Takamoto, T., Okumura, K., Satou, A., Yamada, K., Nakado, T., Zushi, Y., Yamazaki, M. and Yamada, H. (2020) Role of PV-Powered Vehicles in Low-Carbon Society and Some Approaches of High-Efficiency Solar Cell Modules for Cars. Energy and Power Engineering, 12, 375-395. https://doi.org/10.4236/epe.2020.126023

[5] Yamaguchi, M., Masuda, T., Araki, K., Sato, D., Lee, K.-H., Kojima, N., Takamoto, T., Okumura, K., Satou, A., Yamada, K., Nakado, T., Zushi, Y., Ohshita, Y. and Yamazaki, M. (2020) Development of High-Efficiency and Low-Cost Solar Cells for PV-Powered Vehicles Application. Progress in Photovoltaics. https://doi.org/10.1002/pip.3343

[6] Yamaguchi, M., Lee, K.H., Araki, K. and Kojima, N. (2018) A Review of Recent 
Progress in Heterogeneous Silicon Tandem Solar Cells. Journal of Physics D: Applied Physics, 51, Article ID: 133002. https://doi.org/10.1088/1361-6463/aaaf08

[7] Essig, S., Allebé, C., Remo, T., Geisz, J.F., Steiner, M.A., Horowitz, K., Barraud, L., Ward, J.S., Schnabel, M., Descoeudres, A., Young, D.L., Woodhouse, M., Despeisse, M., Ballif, C. and Tamboli, A. (2017) Raising the One-Sun Conversion Efficiency of III-V/Si Solar Cells to $32.8 \%$ for Two Junctions and 35.9\% for Three Junctions. Nature Energy, 2, Article No. 17144. https://doi.org/10.1038/nenergy.2017.144

[8] Müller, R., Schygulla, P., Lackner, D., Höhn, O., Hauser, H., Richter, A., Fell, A., Bläsi, B., Predan, F., Benick, J., Hermle, M., Dimroth, F. and Glunz, S.W. (2020) Silicon-Based Monolithic Triple-Junction Solar Cells with Conversion Efficiency > 34\%. Proceedings of the 37 th European Photovoltaic Solar Energy Conference and Exhibition, Munich, 7-11 September 2020, 574.

[9] Al-Ashouri, A., Köhnen, E., Li, B., Magomedov, A., Hempel, H., Caprioglio, P., Márquez, J.A., Morales Vilches, A.B., Kasparavicius, E., Smith, J.A., Phung, N., Menzel, D., Grischek, M., Kegelmann, L., Skroblin, D., Gollwitzer, C., Malinauskas, T., Jošt, M., Matič, G., Rech, B., Schlatmann, R., Topič, M., Korte, L., Abate, A., Stannowski, B., Neher, D., Stolterfoht, M., Unold, T., Getautis, V. and Albrecht, S. (2020) Monolithic Perovskite/Silicon Tandem Solar Cell with > 29\% Efficiency by Enhanced Hole Extraction. Science, 370, 1300-1309.

https://doi.org/10.1126/science.abd4016

[10] Japanese Ministry of Land, Infrastructure, Transport, and Tourism (2015) Road Traffic Census. (In Japanese) http://www.mlit.go.jp/road/ir/ir-data/ir-data.html

[11] Agency for Natural Resources and Energy (Japanese Ministry of Economy, Trade, and Industry) (2014) Outline of the 2014 Annual Report on Energy (Energy White Paper). 141.

[12] Hara, T., Shiga, T., Kimura, K. and Sato, A. (2016) SAE Technical Paper. Techno-Economic Analysis of Solar Hybrid Vehicles Part 2: Comparative Analysis of Economic, Environmental, and Usability Benefits.

[13] Masuda, T., Araki, K., Okumura, K., Urabe, S., Kudo, Y., Kimura, K., Nakado, T., Sato, A. and Yamaguchi, M. (2017) Static Concentrator Photovoltaics for Automotive Applications. Solar Energy, 146, 523-531. https://doi.org/10.1016/j.solener.2017.03.028

[14] Miyoshi, T. (2017) Solar Charging System for Prius PHV. Journal of the Japan Society of Applied Electromagnetics and Mechanics, 25, 379-382. (In Japanese) https://doi.org/10.14243/jsaem.25.379

[15] Sono Motors. https://sonomotors.com

[16] Ministry of the Environment. http://www.env.go.jp/press/files/jp/114277.pdf

[17] Kanz, O., Reinders, A., May, J. and Ding, K. (2020) Environmental Impacts of Integrated Photovoltaic Module in Light Utility Electric Vehicles. Energies, 13, 5120. https://doi.org/10.3390/en13195120

[18] Japan Electricity Prices, June 2020. GlobalPetrolPrices.com.

[19] Heinrich, M., Kutter, C., Bsler, F., Mittage, M., Alanis, E.L., Eberlein, D., Schmid, A., Reise, C., Kroyer, T., Neuhaus, D.H. and Wirth, H. (2020) Potential and Challenges of Vehicle Integrated Photovoltaics for Passenger Cars. Proceedings of the 37 th European Photovoltaic Solar Energy Conference and Exhibition, Munich, 7-11 September 2020, 1695.

[20] Bloomberg New Energy Finance. https://cleantechnica.com/2020/02/19/bloombergnef-lithium-ion-battery-cell-densit 
ies-have-almost-tripled-since-2010/

[21] Kimura, K., Kudo, Y. and Sato, A. (2016) Techno-Economic Analysis of Solar Hybrid Vehicles Part 1: Analysis of Solar Hybrid Vehicle Potential Considering Well-to-Wheel GHG Emissions. SAE Technical Paper, 2016-01-1287. https://doi.org/10.4271/2016-01-1287

[22] Yamaguchi, M., Warabisako, T. and Sugiura, H. (1994) Chemical Beam Epitaxy as a Breakthrough Technology for Photovoltaic Solar Energy Application. Journal of Crystal Growth, 136, 85. https://doi.org/10.1016/0022-0248(94)90379-4

[23] Horowitz, K.A.W., Remo, T., Smith, B. and Ptak, A. (2018) Techno-Economic Analysis and Cost Reduction Roadmap for III-V Solar Cell. NREL Technical Report, NREL/TP-6A20-72103. https://www.nrel.gov/docs/fy19osti/72103.pdf

[24] Nikkei Business. https://business.nikkei.com/atx/report/15/110879/021500677

[25] Yamaguchi, M., Yamada, H., Katsumata, Y., Lee, K.H., Araki, K. and Kojima, N. (2017) Efficiency Potential and Recent Activities of High-Efficiency Solar Cells. Journal of Materials Research, 32, 3445. https://doi.org/10.1557/jmr.2017.335

[26] Yamaguchi, M., Lee, K.H., Araki, K., Kojima, N., Yamada, H. and Katsumata, Y. (2018) Analysis for Efficiency Potential of High-Efficiency and Next Generation Solar Cells. Progress in Photovoltaics, 26, 543-552. https://doi.org/10.1002/pip.2955

[27] Yamaguchi, M., Zhu, L., Akiyama, A., Kanemitsu, Y., Tampo, H., Shibata, H., Lee, K.H., Araki, K. and Kojima, N. (2018) Analysis of Future Generation Solar Cells and Materials. Japanese Journal of Applied Physics, 57, Article ID: 04FS03. https://doi.org/10.7567/JJAP.57.04FS03

[28] Yamaguchi, M., Lee, K.H., Araki, K., Nakamura, K., Kojima, N. and Ohshita, Y. (2016) Recent Activities of III-V/Si Tandem Solar Cells. The 20 th International Conference on Ternary and Multinary Compounds, Halle, 5-9 September 2016. https://ictmc20.uni-halle.de//page_id=499

[29] Yamaguchi, M., Lee, K.H., Araki, K., Kojima, N. and Ohshita, Y. (2016) Potential and Activities of III-V/Si Tandem Solar Cells. ECS Journal of Solid State Science and Technology, 5, Q68-Q73. https://doi.org/10.1149/2.0311602jss

[30] Takamoto, T., Washio, H., Yamaguchi, H., Ijichi, R., Suzuki, Y., Shimada, K., Takahashi, N. and Ooka, S. (2017) IMM Triple-Junction Solar Cells and Module Optimized for Space and Terrestrial Conditions. The 44th IEEE Photovoltaic Specialist Conference, Washington DC, 25-30 June 2017. https://doi.org/10.1109/PVSC.2017.8366097

[31] Carmody, M., Mallick, S., Margetis, J., Kodama, R., Biegala, T., Xu, D., Bechmann, P., Garland, J.W. and Sivananthan, S. (2010) Single-Crystal II-VI on Si Single-Junction and Tandem Solar Cell. Applied Physics Letters, 96, Article ID: 153502. https://doi.org/10.1063/1.3386529

[32] Sasaki, K., Agui, T., Nakaido, K., Takahashi, N., Onitsuka, R. and Takamoto, T. (2013) Development of InGaP/GaAs/InGaAs Inverted Triple Junction Concentrator Solar Cell. AIP Conference Proceedings, 1556, 22.

https://doi.org/10.1063/1.4822190 